\title{
Vascular Transport of Insulin to Rat Cardiac Muscle Central Role of the Capillary Endothelium
}

Robert S. Bar, Mary Boes, and Alexander Sandra

Departments of Internal Medicine and Anatomy, Veterans Administration Medical Center, Iowa City, Iowa 52240; and Diabetes-Endocrinology Research Center, University of Iowa, Iowa City, Iowa 52240

\begin{abstract}
Using intact, beating hearts, we have assessed the interaction of insulin with capillary endothelium and the subsequent appearance of insulin in cardiac muscle. Rat hearts were perfused with ${ }^{125}$ I-insulin $\left(10^{-10} \mathrm{M}\right)$ alone or in combination with unlabeled insulin $\left(10^{-9}-10^{-5} \mathrm{M}\right){ }^{125} \mathrm{I}$ grains (shown to represent $>90 \%$ intact insulin) over both capillary endothelium and cardiac muscle decreased in a dose-dependent manner when hearts were co-perfused with labeled insulin and increasing concentrations of unlabeled insulin. Perfusion of ${ }^{125} \mathrm{I}$-desoctapeptide (DOP) insulin, a low affinity insulin analogue, with unlabeled insulin $\left(10^{-9}-10^{-5} \mathrm{M}\right)$ had no effect on the appearance of ${ }^{125} \mathrm{I}-\mathrm{DOP}$ insulin over microvessel endothelium and muscle. When capillary receptors were first destroyed by trypsin treatment or blocked by anti-receptor antibodies, the appearance of ${ }^{125} \mathrm{I}$-insulin in cardiac muscle decreased proportional to the inhibition of insulin binding to the capillary receptors. We conclude that insulin binding to capillary endothelial receptors is a central step in the transport of intravascular insulin to rat cardiac muscle.
\end{abstract}

\section{Introduction}

Specific binding sites for insulin are present on the surface of endothelial cells derived from both microvessels and macrovessels (1-7). In certain endothelium, such as capillary endothelial cells, these receptors initiate insulin-stimulated cellular functions that include thymidine incorporation into DNA, glucose conversion to glycogen, and cellular transport of glucose and amino acids $(3,8,9)$. In addition to initiating cellular effects of insulin, the endothelial receptors for insulin may function in the transendothelial transport of biologically intact insulin. When cultured endothelial cells are exposed to insulin, the hormone binds to its cellular surface receptor, is transferred to an intracellular compartment(s), and is then rapidly released from the cell as intact insulin in a manner consistent with transendothelial transport of the hormone (10-13). Such processing of insulin has been documented for endothelial cells cultured from several large-caliber, conducting blood vessels as well as from capillaries.

In the present study, the perfused Langendorff beating heart preparation has been utilized to determine the role of receptor-mediated insulin transfer from the capillary circula-

Received for publication 27 December 1985 and in revised form 11 August 1987.

J. Clin. Invest.

(C) The American Society for Clinical Investigation, Inc.

$0021-9738 / 88 / 04 / 1225 / 09 \$ 2.00$

Volume 81, April 1988, 1225-1233 tion to the subjacent cardiac muscle. The perfused heart preparation has several properties that make it particularly appropriate for such studies. First, we have previously demonstrated that capillary endothelial cells of the beating heart have specific receptors for insulin, as determined by both kinetic and morphometric analysis (7). Second, the perfused heart retains several insulin-mediated functions of cardiac muscle, including stimulation of glucose uptake and lactate production (14-16). Finally, the interendothelial junctions of the heart capillaries are of the "tight" or occluding type. In other capillary beds characterized by similar occluding junctions, neutral molecules the size of insulin cross the endothelium by mechanisms other than diffusion between the cells (17).

\section{Methods}

Preparation of ${ }^{125} I-A_{14}$-insulin and ${ }^{125}$ I-desoctapeptide $(D O P)^{1}$ insulin

${ }^{125} \mathrm{I}-\mathrm{A}_{14}$-insulin was prepared by the method of Lioubin et al. (18). Briefly, insulin (Eli Lilly \& Co., Indianapolis, IN) was iodinated by the lactoperoxidase method and the labeled peptides were applied to a C-18 Porasil precolumn, washed with buffer to eliminate the free ${ }^{125} \mathrm{I}$ iodide, and placed "in line" with a C-18 HPLC column. The monoiodinated ${ }^{125} \mathrm{I}-\mathrm{A}_{14}$-insulin was eluted isocratically with $29 \%$ acetonitrile. Specific activity of the ${ }^{125} \mathrm{I}-\mathrm{A}_{14}$-insulin was $\sim 300 \mu \mathrm{Ci} / \mu \mathrm{g}$ insulin.

${ }^{125} \mathrm{I}-\mathrm{DOP}$ insulin was prepared by stepwise chloramine $\mathrm{T}$ oxidation. The ${ }^{125}$ I-DOP insulin was applied to a Sephadex G-50-40 column (Sigma Chemical Co., St. Louis, MO), with the radioactive peak comigrating with authentic ${ }^{125} \mathrm{I}-\mathrm{A}_{14}$-insulin collected, and the midportion of this peak used for experiments. Specific activities of the ${ }^{125} \mathrm{I}$-DOP insulin ranged from 100 to $150 \mu \mathrm{Ci} / \mu \mathrm{g}$ DOP insulin. The precipitability of ${ }^{125} \mathrm{I}-\mathrm{DOP}$ insulin in 5\% TCA was determined before each experiment and ranged from 92 to $98 \%$. The unlabeled DOP was $\sim 0.1 \%$ as potent as porcine insulin in competing with ${ }^{125} \mathrm{I}$-porcine insulin for insulin receptors on cultured endothelial cells (data not shown). DOP insulin was a kind gift of Dr. Ronald Chance (Eli Lilly \& Co.).

\section{Heart perfusion and fixation}

Rats (CD strain, male, $300 \mathrm{~g}$, Charles River Breeding Laboratory, Wilmington, MA) were anesthetized with methoxyflurane (PitmanMoore, Inc., Washington Crossing, NJ), the chest cavities opened, and the hearts removed and suspended by a perfusion catheter placed in the aorta (7). The isolated heart was perfused in retrograde fashion with perfusate flowing from aorta to coronary arteries to the microvessels, and finally collected via a slit made in the right ventricle. The buffer solution, to which all hormones and other agents were added, consisted of Hanks' balanced salts (pH 7.4) buffered with 15 mM Hepes ( $N-2$ hydroxyethylpiperazine- $N^{\prime}$-2-ethanesulfonic acid) in place of sodium bicarbonate and containing glucose $(1 \mathrm{~g} / \mathrm{liter})$ and fatty acid-poor albumin $(1 \mathrm{mg} / \mathrm{ml})$. Oxygenated buffer and insulin-containing solutions $\left(\mathrm{pH} 7.4,37^{\circ} \mathrm{C}\right.$ ) were perfused using peristaltic pumps at sufficient rate and pressure to close the aortic valve leaflets and maintain the ventricular heart rate at $50-90$ beats/minute.

Autoradiographic analysis of hearts was carried out in the following

1. Abbreviation used in this paper: DOP, desoctapeptide. 
manner. Langendorff hearts were perfused for 2 min with $(a){ }^{125} \mathrm{I}-\mathrm{A}_{14^{-}}$ insulin $\left(10^{-10} \mathrm{M}\right),(b){ }^{125} \mathrm{I}$-DOP insulin $\left(\sim 2 \times 10^{-10} \mathrm{M}\right)$, or $(c)$ with ${ }^{125} \mathrm{I}$-insulin or ${ }^{125} \mathrm{I}$-DOP insulin and varying amounts of unlabeled insulin ranging from $10^{-9}$ to $10^{-5} \mathrm{M}$. The hearts were then immediately perfused with $2.5 \%$ gluteraldehyde in $0.1 \mathrm{M}$ sodium cacodylate

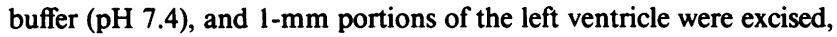
postfixed with $1 \% \mathrm{OsO}_{4}$, dehydrated in graded alcohols, and embedded in Epon. 1- $\mu \mathrm{m}$ sections were cut for light microscopic autoradiography. Slides were coated with Kodak NTB2 emulsion, dried, and stored at $-20^{\circ} \mathrm{C}$ in sealed, light-tight boxes containing dessicant. After 6 to 8 wk, the autoradiographs were developed with Kodak D-19 at $18^{\circ} \mathrm{C}$, cleared with acid fixer, and sections were stained with azure B or toluidine blue. Grain counting over muscle cells and capillaries was carried out using an ocular grid and two cell compartments were analyzed: (i) Muscle cells: grains were counted over randomly selected areas consisting entirely of myocytes within the ocular grid boundaries $\left(25 \mu \mathrm{m}^{2}\right)$. This cellular compartment comprised $>90 \%$ of cardiac tissue. (ii) Capillaries: randomly selected circular profiles of capillaries (average volume density, $7.5 \%$ of total heart tissue) were analyzed by counting grains within $\sim \pm 0.3 \mu \mathrm{m}$ (one grain diameter) diameter of the capillary endothelial boundary. The vast majority of grains associated with capillaries are included in this compartment. Since the average heart capillary under these conditions measured $4.8 \mu \mathrm{m}$ in diameter (range, 3.2 to $9.0 \mu \mathrm{m}$ of $>150$ vessels from each of three separate hearts), the average area analyzed per capillary was $\sim 4.5$ $\mu \mathrm{m}^{2}$. In each case, the density of background silver grains was subtracted from the density of silver grains over cells to give the specific number of grains per unit area. For each point, 130 to 160 individual determinations were made from each of three separate hearts and reported as the average \pm SEM.

\section{Trypsin and anti-insulin receptor antibody studies}

Trypsin. Hearts were perfused with several concentrations of trypsin (Difco Laboratories, Inc., Detroit, MI) ranging from 1 to $0.05 \%$ for 1 min, followed by perfusion with buffer for $30 \mathrm{~s}$. The hearts were then perfused with ${ }^{125} \mathrm{I}$-insulin $\left(10^{-10} \mathrm{M}\right)$ alone or ${ }^{125} \mathrm{I}$-insulin plus unlabeled insulin at $10^{-5} \mathrm{M}$ and processed for radioautography as previously described. Several sections of myocardium were prepared from each trypsin-treated heart for assessment of morphologic integrity by electron microscopic evaluation. Perfusion with trypsin at $0.2 \%$ or less did not alter the heart beat rate; perfusion at $1 \%$ trypsin caused slowing of heart rate, which was reversed with subsequent perfusion with buffer alone.

Anti-receptor antibodies. Serum containing anti-insulin receptor antibodies from patient B-7 was used for these studies (19). The effect of serum B-7 on insulin binding to cultured cells was assessed in microvessel endothelial cells cultured from bovine adipose tissue (9) and studied after one passage in vitro. Monolayer cells in 6-well trays were incubated at $22^{\circ} \mathrm{C}$ for $1 \mathrm{~h}$ with serum B-7 at dilutions of $1: 50$ and $1: 250$, the cells washed and assayed for insulin binding using ${ }^{125} \mathrm{I}_{-} \mathrm{A}_{14^{-}}$ insulin as previously described (9).

For heart perfusions, serum B-7 was co-perfused at each of two dilutions, $1: 50$ and 1:250, with ${ }^{125}$ I-insulin $\left(10^{-10} \mathrm{M}\right)$ for periods of 30 , 60 , and $120 \mathrm{~s}$. After the designated perfusion period the hearts were processed for autoradiographs as previously described. In all experiments, perfusion with serum B-7 did not alter the heart rate of the preparations.

Passage of serum Igs into cardiac muscle was assessed in two ways. First, beating hearts were perfused with either serum B-7, control serum, or buffer, then rapidly fixed. Thin sections (silver-gold, $\sim 0.05$ $\mu \mathrm{m})$ were cut and incubated with $(a)$ colloidal gold-labeled protein A (20) diluted to $E_{520}=0.05$ according to the method of Roth et al. (20), and $(b)$ several concentrations of colloidal gold-labeled goat antihuman IgG (Polysciences, Inc., Worthington, PA; gold particle diameter, $15-20 \mathrm{~nm}$ ) for $2 \mathrm{~h}$ at $20^{\circ} \mathrm{C}$ in $10 \mathrm{mM}$ Tris- $\mathrm{HCl}, \mathrm{pH} \mathrm{7.4}$. Since maximal numbers of specific gold particles were observed at a dilution of gold anti-IgG of $1: 10$, results are reported at this concentration. Sections were jet washed with double-distilled water, dried, photo- graphed using a Hitachi $\mathrm{H} 600$ electron microscope, and negatives printed at 16,000 to 20,000 times final magnification. Areas of muscle were computed by a Zeiss MOPP digitizer and the gold particles quantitated. Second, serum from patient B-7 and control serum were precipitated with ammonium sulfate (33\% final concentration), the precipitate redissolved in phosphate buffer $\left(0.01 \mathrm{M} \mathrm{KH}_{2} \mathrm{PO}_{4}, \mathrm{pH} 8\right)$, and dialyzed for $24 \mathrm{~h}$ in phosphate buffer, using dialysis tubing with a 3,500 D cutoff range. The retained material was concentrated and iodinated with ${ }^{125} \mathrm{I}$ using chloramine $\mathrm{T}$ oxidation to a final specific activity of $10-15 \mu \mathrm{Ci} / \mu \mathrm{g}$ protein as previously described by Jarrett et al. (21). Additionally, the ammonium sulfate precipitates were further resolved on DEAE ion exchange chromatography according to the procedure of Jarrett et al. (21). The DEAE-purified material was also concentrated, iodinated with ${ }^{125}$ I to a specific activity of $\sim 10-15$ $\mu \mathrm{Ci} / \mu \mathrm{g}$ protein. The iodinated material from the ammonium sulfate precipitation and the DEAE columns then were each used in heart perfusions as previously described for ${ }^{125} \mathrm{I}$-insulin perfusion. Serum B-7 was a generous gift of Dr. P. Gorden (National Institutes of Health, Bethesda, MD).

\section{Results}

\section{Nature of ${ }^{125}$ I grains over capillaries and cardiac muscle}

Before analyzing the radioautographic data of the perfused heart, the chemical nature of the ${ }^{125}$ I grains over capillaries and muscle was first determined in hearts that had been perfused with ${ }^{125}$ I-insulin. In similar heart perfusion experiments with ${ }^{125}$ I-insulin, we have previously demonstrated that the radioac-

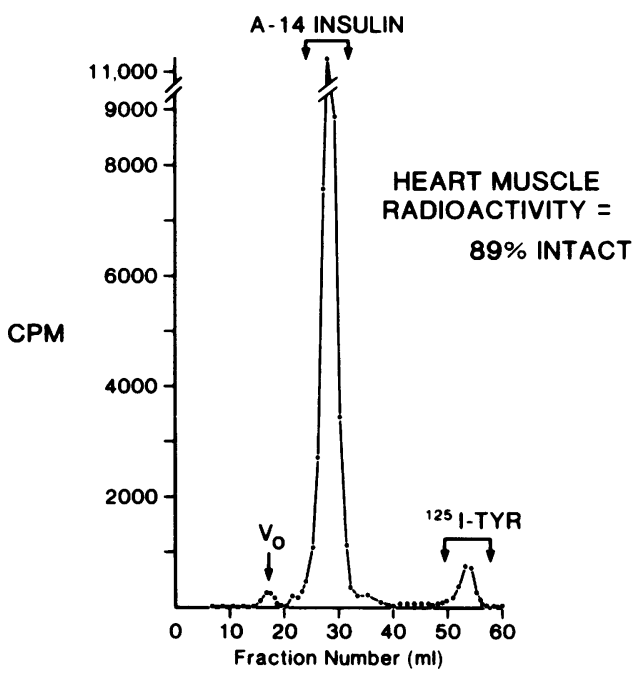

Figure 1. Gel chromatography of radioactivity associated with cardiac muscle. A rat heart was perfused with ${ }^{125}$ I-insulin $\left(10^{-10} \mathrm{M}\right)$ for $2 \mathrm{~min}$, followed by perfusion with unlabeled insulin $\left(10^{-5} \mathrm{M}\right)$ for 1 min, followed by trypsin solution (1\%) for $1 \mathrm{~min}$. Several small sections $\left(1 \mathrm{~mm}^{3}\right)$ of the left ventricular epicardium were excised, radioautographs prepared and developed, and shown to have virtually all ${ }^{125}$ I-grains localized over cardiac muscle. The heart was then minced, sonicated times two in buffer that contained Triton X-100 $(0.1 \%)$, bacitracin $\left(10^{-3} \mathrm{M}\right)$, phenylmethylsulfonyl fluoride $(0.92$ $\mathrm{mM})$, and $N$-ethylmaleimide $(10 \mathrm{mM})$, and centrifuged at $200,000 \mathrm{~g}$ for $30 \mathrm{~min}$ at $10^{\circ} \mathrm{C}$. Aliquots of the supernatant which contained $95 \%$ of the total heart radioactivity were applied to a Sephadex G-50-40 column $(55 \times 0.9 \mathrm{~cm})$ and eluted with buffer containing 4 $\mathrm{M}$ urea, $1 \mathrm{M}$ acetic acid, and protease inhibitors at $1.25 \mathrm{ml} / \mathrm{h}$. The column run was calibrated with markers for the void volume (dextran blue), ${ }^{125} \mathrm{I}$-insulin, $\mathrm{Na}{ }^{125} \mathrm{I}$, and $\left[{ }^{125} \mathrm{I}\right]$ tyrosine standards. In eight such experiments radioactivity co-eluting with ${ }^{125}$ I-insulin standard represented $80-95 \%$ of the total heart radioactivity. 

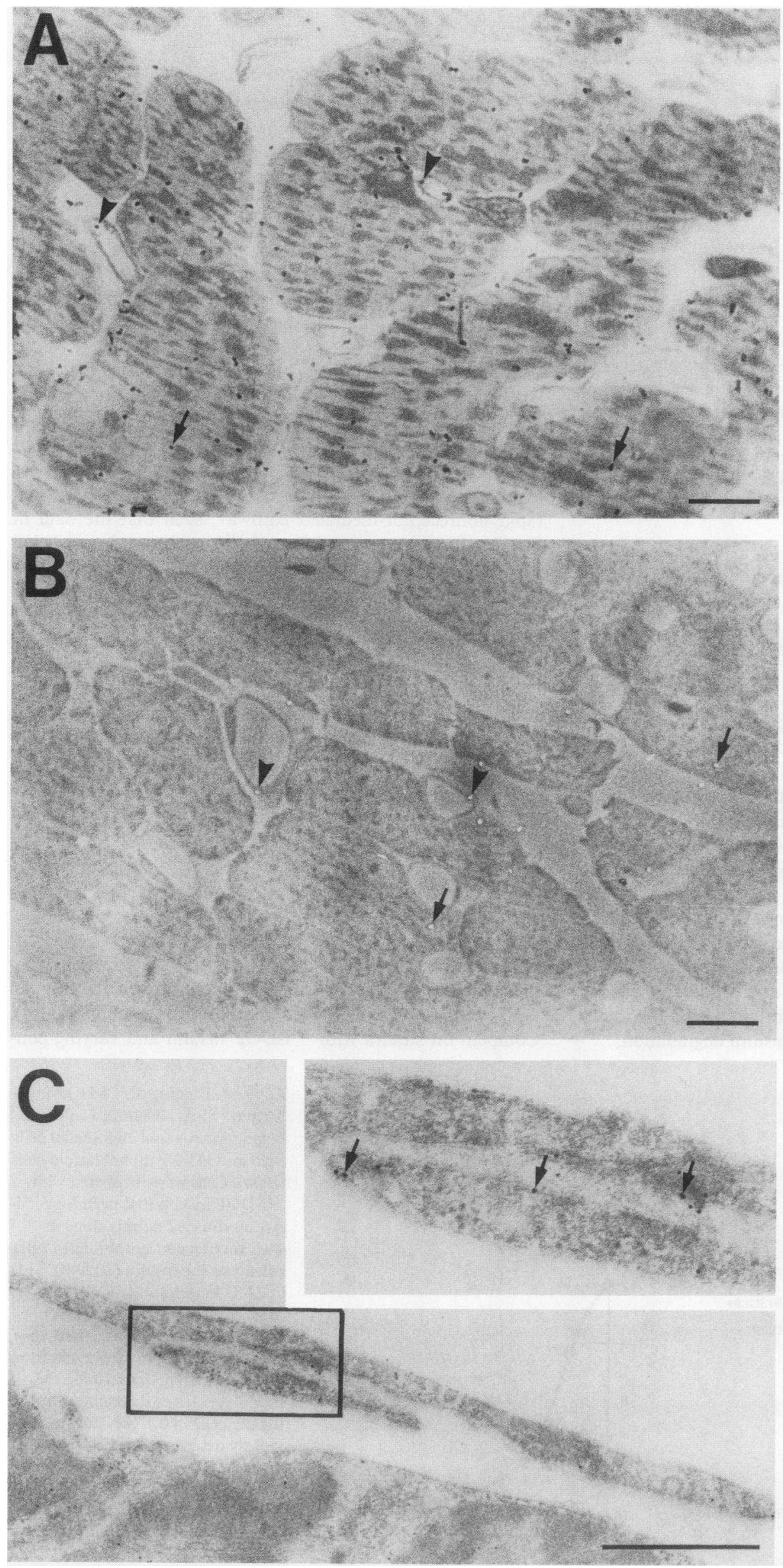

Figure 2. Micrographs depicting the morphological appearance of the isolated rat heart after perfusion with $(A)$ ${ }^{125} \mathrm{I}-\mathrm{A}_{14}$ insulin at $10^{-10} \mathrm{M}$ for $2 \mathrm{~min}$, photographed by bright field; $(B)^{125} \mathrm{I}$ labeled IgG from anti-receptor serum diluted 1:50, photographed by dark field. Tissue was prepared for light level autoradiography as described in Methods. In each case, arrowheads illustrate silver grains localized to the capillary endothelium and arrows to the muscle compartment. In $C$, anti-receptor serum IgG was further localized predominantly to the microvascular endothelium by postembedding staining with colloidal gold anti-IgG. Magnification bars: $A$ and $B, 10 \mu \mathrm{m} ; C, 1 \mu \mathrm{m}$. For inset in $C, \times 54,400$. 

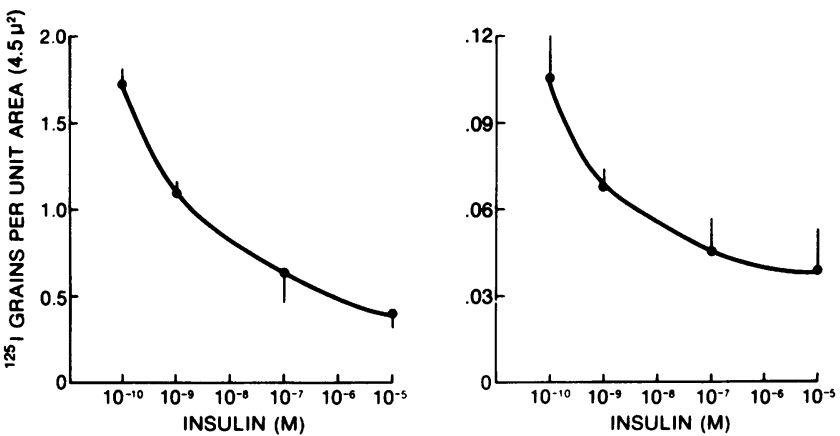

Figure 3. Analysis of ${ }^{125} \mathrm{I}$-insulin grains over capillaries (left) and cardiac muscle (right) in hearts perfused with ${ }^{125} \mathrm{I}$-insulin. ${ }^{125} \mathrm{I}$-Insulin was perfused at $10^{-10} \mathrm{M}$ alone or with varying concentrations of unlabeled porcine insulin $\left(10^{-9}-10^{-5} \mathrm{M}\right)$ for $2 \mathrm{~min}$, then rapidly fixed with gluteraldehyde perfusion and subsequently assayed for ${ }^{125} \mathrm{I}$ grains over capillaries and cardiac muscle. The data represent the mean \pm SEM for three separate hearts with counts of 130 to 160 grains per heart.

tivity associated with capillaries represents intact ${ }^{125} \mathrm{I}$-insulin (7). To characterize the muscle radioactivity, ${ }^{125}$ I-insulin was perfused through the heart for $2 \mathrm{~min}$ and the ${ }^{125} \mathrm{I}$-insulin removed from the vascular system by rapid perfusion with excess cold insulin and then trypsin $(1 \%, 30 \mathrm{~s})$. In such preparations, the remaining radioactivity was shown to overlay cardiac muscle by autoradiographic examination. After trypsin treatment, the hearts were minced and sonicated in the presence of $0.1 \%$ Triton X-100 and several protease inhibitors (10 $\mathrm{mM} N$-ethylmaleimide, $0.92 \mathrm{mM}$ phenylmethylsulfonyl fluoride, and $1 \mathrm{mM}$ bacitracin). The solubilized material was then chromatographed on Sephadex G-50-40 to assess the nature of the solubilized radioactivity. In eight experiments, the amount of intact ${ }^{125} \mathrm{I}$-insulin (i.e., radioactivity co-eluting with ${ }^{125} \mathrm{I}$-insulin standard) over cardiac muscle ranged from 80 to $95 \%$ of the total radioactivity, with the example shown in Fig. 1 representing $89 \%$ intact ${ }^{125} \mathrm{I}$-insulin. Therefore, as previously shown for ${ }^{125} \mathrm{I}$ grains over capillaries (7), the ${ }^{125} \mathrm{I}$-radioautographic grains over cardiac muscle predominantly reflected the intact insulin molecule and not products of insulin degradation.
Heart perfusions with ${ }^{125}$ I-insulin

${ }^{125} \mathrm{I}$-Insulin $\left(10^{-10} \mathrm{M}\right)$ was perfused through the beating hearts for $2 \mathrm{~min}$ by itself or with varying concentrations of unlabeled insulin. The tissues were then fixed and subsequently analyzed for radioautographic grain counts over capillaries and cardiac muscle (Fig. $2 A$ ). Grain counts over both capillaries and muscle were maximal when ${ }^{125}$ I-insulin was perfused alone and decreased progressively in both capillary and muscle compartments as increasing concentrations of unlabeled insulin were co-perfused with the ${ }^{125} \mathrm{I}$-insulin (Fig. 3). Unlabeled insulin at $10^{-5} \mathrm{M}$ decreased grain numbers over capillaries by $76 \%$ and over muscle by $71 \%$.

There are at least three possible explanations for the correlations between muscle ${ }^{125} \mathrm{I}$-insulin and capillary-bound ${ }^{125} \mathrm{I}$ insulin: ( $i$ ) Insulin could alter capillary endothelial permeability in a nonspecific manner that affects the transendothelial passage of all molecules with similar size and net charge as insulin; (ii) Insulin transfer across the capillaries occurs via a rapid nonreceptor-mediated pathway, such that the data in Fig. 3 reflect the competition of ${ }^{125}$ I-insulin with unlabeled insulin at two separate receptors, one in the capillary endothelial cells and the other in cardiac muscle; or (iii) Insulin passage to cardiac muscle from the capillary vascular compartment is mediated by capillary endothelial cell receptors for insulin. We evaluated the first possible mechanism by utilizing ${ }^{125}$ I-DOP insulin, an insulin analogue having similar size, structure, and charge as native insulin but with little affinity for insulin receptors. We tested the second and third possible mechanism by destroying capillary insulin receptors with trypsin or blocking the capillary receptors with anti-insulin receptor antibodies. After trypsin and antibody treatments the autoradiographic grain distribution studies with ${ }^{125}$ I-insulin were repeated.

\section{${ }^{125}$ I-DOP insulin}

Characterization. The binding properties of the ${ }^{125} \mathrm{I}-\mathrm{DOP}$ insulin were first evaluated in both cultured microvessel endothelial cells and cultured IM-9 lymphoblastoid cells, two cell types with well-characterized receptors for insulin (Fig. 4). Competition studies with ${ }^{125}$ I-DOP insulin and varying con-
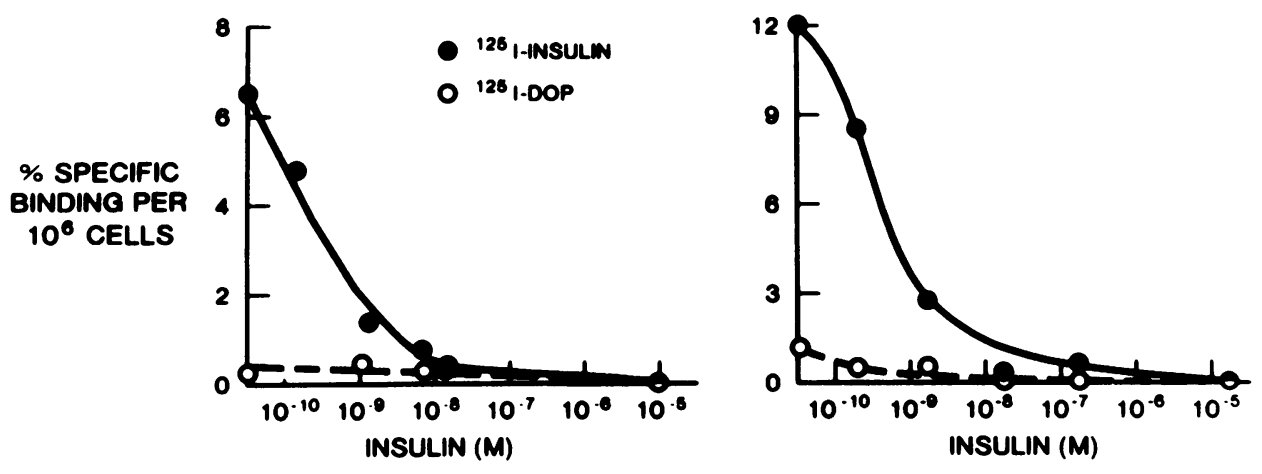

Figure 4. Binding of ${ }^{125} \mathrm{I}-\mathrm{DOP}$ insulin and ${ }^{125} \mathrm{I}-\mathrm{A}_{14}$ insulin to cultured bovine microvessel endothelial cells (left) and IM-9 lymphoblastoid cells $(r i g h t)$. Cells were incubated with ${ }^{125} \mathrm{I}-\mathrm{DOP}$ insulin $(0.2 \mathrm{ng} / \mathrm{ml})$ or ${ }^{125} \mathrm{I}$ $\mathrm{A}_{14}$ insulin $(0.2 \mathrm{ng} / \mathrm{ml})$ alone or with varying concentrations of unlabeled porcine insulin $\left(10^{10}-10^{-5} \mathrm{M}\right)$ at $22^{\circ} \mathrm{C}$ for $90 \mathrm{~min}$ (endothelial cells) or $15^{\circ} \mathrm{C}$ for $90 \mathrm{~min}$ (IM-9 cells). Cell-bound radioactivity in endothelial cells was separated from free radioactivity by washing the monolayer times three and dissolving the cells in $0.1 \mathrm{~N} \mathrm{NaOH}$ as previously described (9). Cell-bound radioactivity in IM-9 cells was determined by centrifugation.

Nonspecific binding was $10 \%$, and degradation of labeled hormone $\sim 3 \%$ for both cell types. 

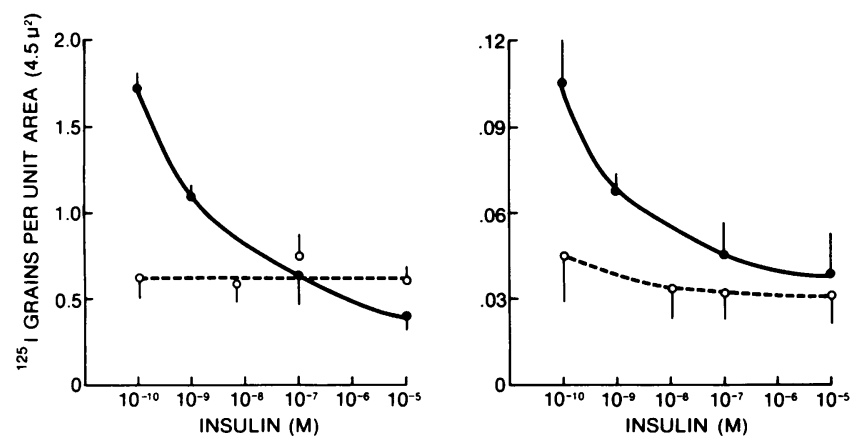

Figure 5. Analysis of ${ }^{125}$ I grains over capillaries (left) and cardiac muscle (right) in hearts perfused with ${ }^{125} \mathrm{I}$-insulin $(\bullet)$ or ${ }^{125} \mathrm{I}$-DOP insulin (0). ${ }^{125} \mathrm{I}$-Hormone was perfused at $10^{-10} \mathrm{M}$ alone or with varying concentrations of unlabeled porcine insulin $\left(10^{-9}-10^{-5} \mathrm{M}\right)$ for 2 min, than rapidly fixed by gluteraldehyde perfusion and subsequently analyzed by quantitative autoradiography. Similar counts per minute of ${ }^{125} \mathrm{I}$-insulin and ${ }^{125} \mathrm{I}$-DOP insulin were used to perfuse the hearts in these studies. The data represent the mean \pm SEM for three separate hearts with 130 to 160 grains counted per heart.

centrations of unlabeled insulin are shown in Fig. 4 and compared with analogous studies using ${ }^{125} \mathrm{I}$-insulin. At tracer concentrations of labeled hormone $(0.2 \mathrm{ng} / \mathrm{ml}),{ }^{125} \mathrm{I}$-insulin binds with considerably higher affinity to cellular receptors than does ${ }^{125} \mathrm{I}$-DOP insulin. In microvessel endothelial cells, tracer binding of ${ }^{125} \mathrm{I}$-insulin was 6 vs. $0.2 \%$ for ${ }^{125} \mathrm{I}$-DOP insulin when normalized to $10^{6}$ cells (Fig. 4, left), while in the IM-9 cells, maximal binding of ${ }^{125} \mathrm{I}$-insulin was 12 vs. $1.2 \%$ for ${ }^{125} \mathrm{I}$ DOP insulin (Fig. 4, right).

Heart perfusion. Heart perfusions similar to those described for ${ }^{125} \mathrm{I}$-insulin were performed using ${ }^{125} \mathrm{I}$-DOP insulin (Fig. 5). To facilitate comparison with the ${ }^{125} \mathrm{I}$-insulin studies, similar numbers of counts of ${ }^{125} \mathrm{I}$-DOP insulin were perfused for identical time periods $(2 \mathrm{~min})$. Two major differences are apparent when ${ }^{125} \mathrm{I}$-DOP insulin is used as the labeled ligand (Fig. 5, dashed line). First, at tracer concentrations, fewer grains of ${ }^{125} \mathrm{I}-\mathrm{DOP}$ insulin are present over both capillaries and muscle, i.e., $63 \%$ less than ${ }^{125} \mathrm{I}$-insulin over capillaries and $58 \%$ less over muscle. Second, co-perfusion with any concentration of unlabeled insulin does not change the amount of ${ }^{125} \mathrm{I}-\mathrm{DOP}$ insulin over the capillaries and only inhibits muscle grains slightly. All ${ }^{125}$ I-DOP insulin grain counts in Fig. 5 are highly significant, being 6-13-fold above background at each point, with the emulsion background for the capillary and muscle compartments averaging $0.1 \pm 0.01$ grains $/ 4.5 \mu \mathrm{m}^{2}$ (capillary) and $0.02 \pm 0.001$ grains $/ 4.5 \mu \mathrm{m}^{2}$ (muscle). Furthermore, with the low background and relatively small variability of data, we should have easily detected decreases from maximal grain counts (i.e., ${ }^{125} \mathrm{I}$-DOP at $10^{-10} \mathrm{M}$ ) had they occurred. Therefore, it is unlikely that insulin, at any concentration, resulted in a nonspecific decrease in capillary permeability to molecules of the size of insulin.

\section{Trypsin and anti-insulin receptor antibody studies}

Trypsin treatments. Hearts were perfused for $1 \mathrm{~min}$ with tryp$\sin (1,0.2$, or $0.05 \%)$, then with buffer for $30 \mathrm{~s}$, and finally with ${ }^{125}$ I-insulin $\left(10^{-10} \mathrm{M}\right)$ alone or ${ }^{125} \mathrm{I}$-insulin $\left(10^{-10} \mathrm{M}\right)$ plus unlabeled insulin at $10^{-5} \mathrm{M}$. Hearts were prepared for both morphologic (electron microscopy) and light level radioautographic analysis. When hearts were perfused with $1 \%$ trypsin, electron microscopic evaluation of capillary ultrastructure demonstrated significant convolutions and areas of disruption of the lumenal endothelial cell surface (Fig. $6 \mathrm{~B}$ ). In contrast, at the lower concentrations of trypsin $(0.2$ and $0.05 \%)$, detailed electron microscopy analysis demonstrated normal capillary endothelial morphology (Fig. 6, $C$ and $D$ ). No obvious morphological alterations were detected in the muscle compartment at any trypsin concentration. Fig. 7 summarizes the autoradiographic results. Both 1 and $0.2 \%$ trypsin preperfusion resulted in significant loss of capillary binding sites for insulin, with capillary ${ }^{125} \mathrm{I}$-insulin binding being $52 \%$ less than control for $1 \%$ trypsin and $40 \%$ less than control for hearts treated with $0.2 \%$ trypsin. Trypsin at $0.05 \%$ did not reduce capillary binding sites for insulin. For hearts treated with 1 and $0.2 \%$ trypsin, the remaining capillary binding sites demonstrated competition of binding when unlabeled insulin $\left(10^{-5} \mathrm{M}\right)$ was co-perfused with ${ }^{125}$ I-insulin (Fig. 7).

Autoradiographic analysis of the muscle compartments of hearts treated with 1 and $0.2 \%$ trypsin demonstrated different results. With $1 \%$ trypsin treatment, muscle counts were increased to $160 \%$ of control despite the marked decrease in capillary binding in the same hearts. When considered in the context of the morphologic findings of endothelial cell disruption with $1 \%$ trypsin, the data with $1 \%$ trypsin are most consistent with major transendothelial leaks induced by the trypsin treatment. The observation that unlabeled insulin did not compete for the majority of ${ }^{125} I$ grains in the muscle compartment could reflect "nonspecific" trapping of ${ }^{125} \mathrm{I}$-insulin or possible degradation of ${ }^{125} \mathrm{I}$-insulin and deposition of ${ }^{125} \mathrm{I}$ degradation products in the muscle compartment. The $0.2 \%$ trypsin-treated hearts showed decreased ${ }^{125}$ I grains in the muscle compartment ( $32 \%$ less than control) that were approximately proportional to the decrease in grain density observed at the capillary endothelial sites for insulin binding. Finally, perfusion of hearts with the lower trypsin concentration, $0.05 \%$, resulted in no effect on grain counts over capillaries or muscle.

Hearts that were preperfused with trypsin at $0.2 \%$ were also analyzed for the nature of ${ }^{125} \mathrm{I}$ after the 2 -min perfusion with ${ }^{125}$ I-insulin, and found to be similar to hearts that were perfused with buffer only (Fig. 1), i.e., $>90 \%$ of ${ }^{125} \mathrm{I}$ remained in the form of intact ${ }^{125} \mathrm{I}$-insulin.

Anti-insulin receptor antibodies. Serum obtained from patient B-7 was used in these studies (19). This patient had a severe form of insulin resistance caused by the presence of anti-insulin receptor antibodies in her circulation. Her serum, referred to as serum B-7, contained anti-insulin receptor antibodies predominantly of the IgG class. In the present studies serum B-7, at dilutions of 1:50 and 1:250, was co-perfused through hearts with ${ }^{125}$ I-insulin $\left(10^{-10} \mathrm{M}\right)$ for periods of 30,60 , and $120 \mathrm{~s}$, and the hearts then analyzed autoradiographically for ${ }^{125} \mathrm{I}$ grains in the capillary and muscle compartments (Fig. 2 $B$ and Fig. 8). At a 1:50 dilution, serum B-7 inhibited insulin binding to capillaries with capillary-bound ${ }^{125} \mathrm{I}$-insulin being 45,68 , and $85 \%$ less than control after 30,60 , and $120 \mathrm{~s}$ of perfusion, respectively (Fig. 8, left). ${ }^{125}$ I-Insulin appearing over muscle showed decreases that were, in general, proportional to the decreased binding to the capillaries, being 62,63 , and $69 \%$ less than control at 30,60 , and $120 \mathrm{~s}$ of perfusion. When studies were performed at serum dilutions of 1:250 a similar correlation between capillary binding of ${ }^{125} \mathrm{I}$-insulin and appearance of ${ }^{125} \mathrm{I}$-insulin in muscle was also observed. When the anti-receptor antibody serum caused little change in capillary 

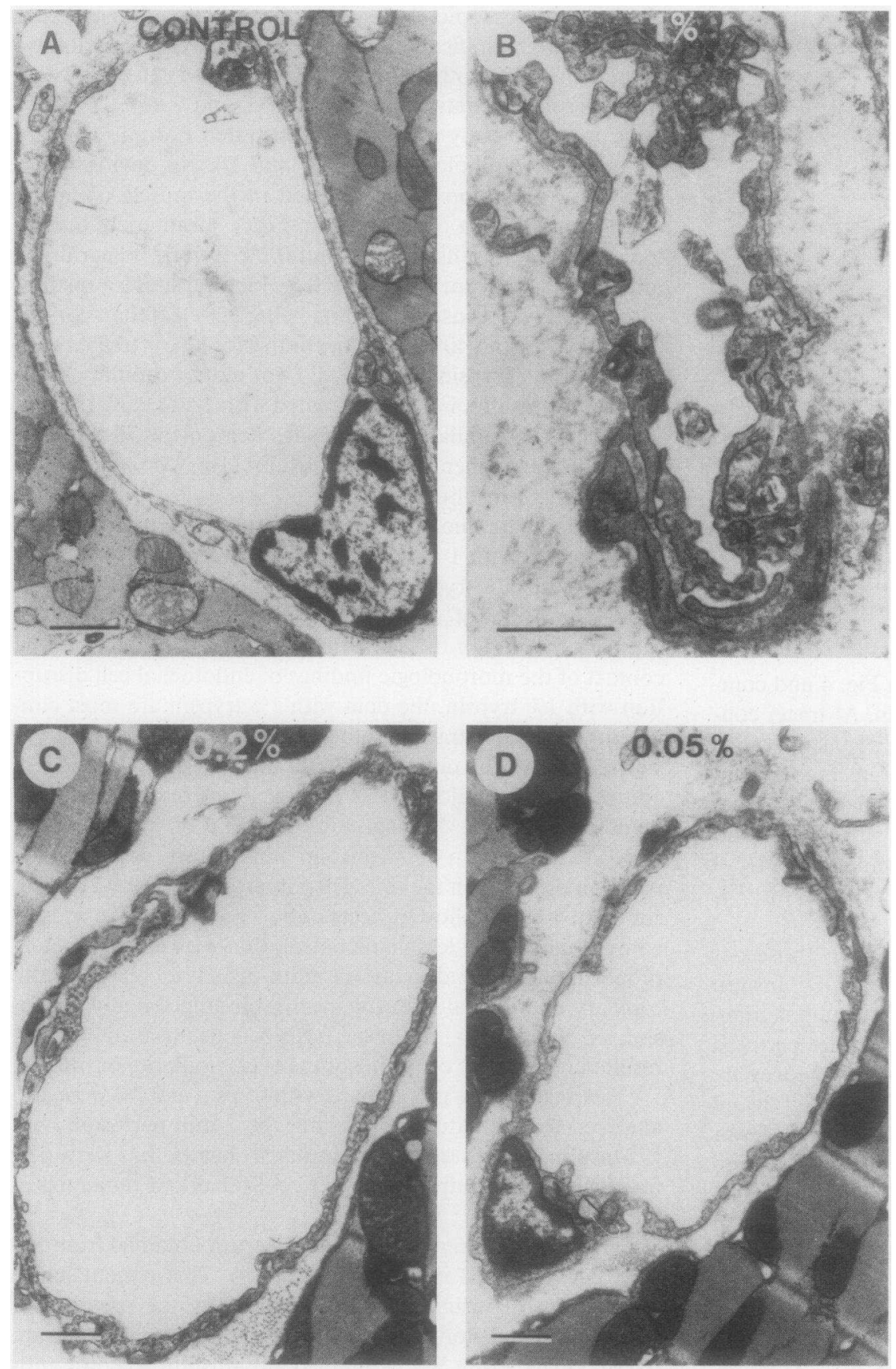

Figure 6. Ultrastructure appearance of heart capillaries after 1-min perfusion with $1,0.2$, and $0.05 \%$ trypsin. Magnification bar, $1 \mu \mathrm{m}$.

binding of insulin (i.e., 30-s perfusion at a 1:250 serum dilution), there was little change in the muscle ${ }^{125} \mathrm{I}$-insulin. However, as greater effects of the serum were observed with longer perfusion periods, i.e., at 60 and $120 \mathrm{~s}$ of perfusion with a 1:250 serum dilution, capillary binding was 51 and $87 \%$ less than control, and the corresponding reduction in muscle ${ }^{125} \mathrm{I}$ insulin was 60 and $74 \%$ less than control. The anti-receptor antibody serum did not alter the heart rates at either serum dilution.

For comparison to the potency of serum B-7 in inhibiting insulin binding in cultured cells, serum B-7 at a dilution of 1:50 inhibited ${ }^{125} \mathrm{I}$-insulin binding to cultured bovine microvessel endothelial cells by $93 \%$, and at a $1: 250$ dilution by $81 \%$.

We next sought to determine whether significant anti-re- ceptor antibodies were transferred to cardiac muscle under the conditions of these experiments. Although existing literature of IgG transcapillary transport makes such a consideration unlikely, it was possible that anti-receptor IgGs are transferred to cardiac muscle based on their selective affinity for capillary endothelial receptors for insulin. Two indirect experimental approaches were used. First, serum B-7 or control serum was perfused through rat hearts at a 1:50 dilution for $30 \mathrm{~s}$ or at a 1:250 dilution for $90 \mathrm{~s}$, the hearts fixed and subsequently treated with colloidal gold-labeled anti-human IgG or protein A gold. Gold particles were then quantified on electron microscopic prints of randomly chosen areas of capillaries and cardiac muscle (Fig. $2 C$ ). With both gold labels, $\sim 99 \%$ of gold particles were found in the capillary compartment, a few gold 


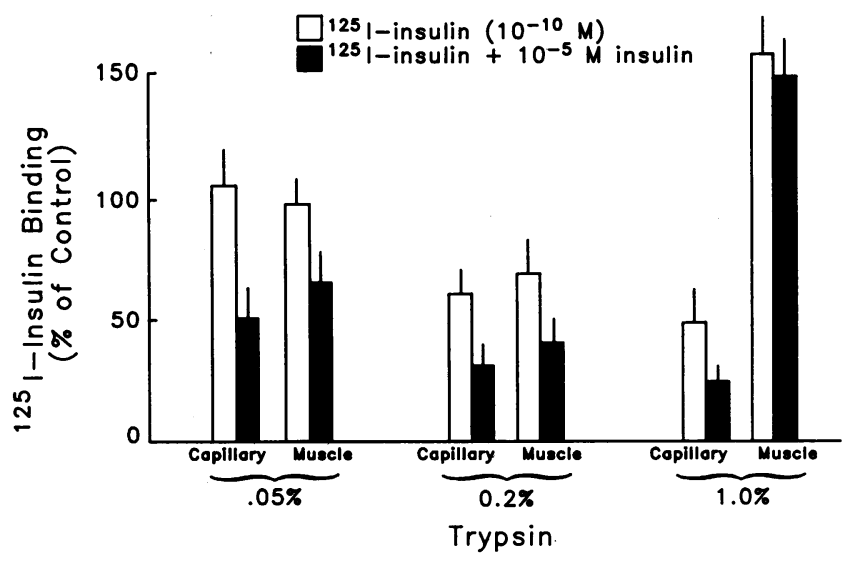

Figure 7. Analysis of ${ }^{125}$ I-insulin grains over capillaries and muscle after heart perfusion with trypsin. Hearts were initially perfused with trypsin $(0.05,0.2$, and $1.0 \%)$ for $1 \mathrm{~min}$ followed by perfusion with buffer for $30 \mathrm{~s}$. The hearts were then perfused with ${ }^{125} \mathrm{I}$-insulin $\left(10^{-10}\right.$ $\mathrm{M}$ ) alone or ${ }^{125} \mathrm{I}$-insulin plus unlabeled insulin at $10^{-5} \mathrm{M}$ and processed for radioautography as previously described. Several sections of myocardium were prepared from each trypsin-treated heart for assessment of morphologic integrity by electron microscopic evaluation. Data are expressed as percent of ${ }^{125} \mathrm{I}$ grain counts when ${ }^{125} \mathrm{I}$-insulin $\left(10^{-10} \mathrm{M}\right)$ was perfused through hearts treated with buffer only with no trypsin preperfusion. Each bar represents the mean \pm 1 SEM of three separate hearts with $\sim 200$ grains counted per heart.

particles were found in interstitial spaces, and only an occasional gold particle was located in the muscle compartment (Table I). Second, Ig-enriched fractions of sera obtained by both $33 \%$ ammonium sulfate precipitation and DEAE ion exchange chromatography of serum B-7 and control serum were prepared and iodinated with ${ }^{125} \mathrm{I}$ at $\sim 10-15 \mu \mathrm{Ci} / \mu \mathrm{g}$ protein. Because limited transfer of Ig was anticipated, the labeled Igs were perfused through the hearts at significantly higher counts per minute than was used in studies with ${ }^{125}$ I-insulin perfusion. Labeled Ig preparations of control serum, both 33\% ammonium sulfate precipitates of B-7 serum, and DEAE ion exchange chromatography of B-7 serum corresponding to a 1:50 dilution of serum $\left(\sim 60 \times 10^{6} \mathrm{cpm} / \mathrm{ml}\right)$ were perfused for $30 \mathrm{~s}$, and ${ }^{125} \mathrm{I}-\mathrm{Ig}$ preparations corresponding to a 1:250 serum dilu-

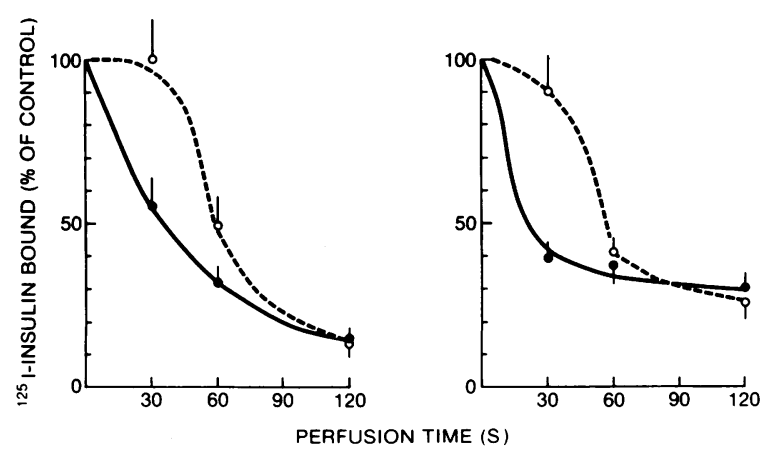

Figure 8. Effect of anti-insulin receptor antibody serum on ${ }^{125}$ I-insulin binding to capillaries (left) and muscle (right) of the perfused, beating heart. Serum B-7, at 1:50 (•) and 1:250(0) dilutions, was coperfused with ${ }^{125} \mathrm{I}$-insulin $\left(10^{-10} \mathrm{M}\right)$ for 30,60 , or $120 \mathrm{~s}$, and the hearts were fixed and analyzed for ${ }^{125} \mathrm{I}$ grains over capillaries and muscle as described in Methods. Each point represents the mean \pm SEM of three separate hearts. tion $\left(\sim 12 \times 10^{6} \mathrm{cpm} / \mathrm{ml}\right)$ were perfused for $90 \mathrm{~s}$, then prepared for radioautography. Autoradiographs were developed for identical periods as hearts exposed to ${ }^{125} \mathrm{I}$-insulin only $(\sim 2$ $\times 10^{6} \mathrm{cpm}{ }^{125} \mathrm{I}$-insulin/ml). For the ${ }^{125}$ I-labeled serum preparations (control and B-7), $\sim 99 \%$ of grains were localized to capillaries with $<1 \%$ of grains in the muscle compartment (Table I). For comparison with ${ }^{125}$ I-insulin a substantially greater proportion of ${ }^{125} \mathrm{I}$ grains was found in muscle. The ratio of ${ }^{125}$ I-insulin in muscle versus capillary ranged from oneeighth to one-twelfth for insulin compared with less than one one-hundreth for both B-7 and control serum. At a 1:50 equivalent dilution of serum, perfused for $30 \mathrm{~s}$, serum B-7 yielded $0.10 \pm 0.03$ grains $/ \mu \mathrm{m}^{2}$ cardiac muscle, control serum $0.12 \pm 0.04 / \mu \mathrm{m}^{2}$, and for insulin $0.56 \pm 0.06$ grains $/ \mu \mathrm{m}^{2}$ cardiac muscle. At a 1:250 serum dilution, perfused for $90 \mathrm{~s}$, serum B-7 yielded $0.35 \pm 0.15$ grains, control serum $0.30 \pm 0.18$ grains, and insulin-treated hearts $1.67 \pm 0.2$ grains $/ \mu \mathrm{m}^{2}$ cardiac muscle. Taken together, these two studies indicate that little, if any, antibody reached cardiac muscle, and that the hearts do not have a markedly facilitated cardiac uptake of anti-receptor antibodies, at least within the short exposure times of the present study.

\section{Discussion}

We have utilized a functioning, intact heart perfusion system to assess the role of capillary endothelial cell receptors for insulin in the transfer of the hormone to its major subendothelial site of action, cardiac muscle. When ${ }^{125}$ I-insulin $\left(10^{-10}\right.$ M) was co-perfused with unlabeled insulin, the number of ${ }^{125} I$ grains over capillaries decreased in direct proportion to the concentration of unlabeled insulin. Such conditions resulted in a similar dose-dependent decrease in ${ }^{125}$ I grain density over cardiac muscle. Since the ${ }^{125}$ I grains over capillaries and muscle represent intact insulin, and since the capillary grains have previously been shown to be localized to endothelial cells (7), the data indicate that blocking capillary endothelial cell receptors for insulin is associated with decreases in the appearance of ${ }^{125}$ I-insulin in cardiac muscle that are proportional to the percentage of "blocked" capillary receptors.

Table I. Localization of ${ }^{125}$ I Grains and Gold Particles in Hearts Perfused with Control Serum or B-7 Serum

\begin{tabular}{cccccc}
\hline & \multicolumn{2}{c}{${ }^{125}$ I Grains* } & & & \multicolumn{2}{c}{ Gold (anti-gold IgG) } \\
Serum & Capillary & Muscle & & Capillary & Muscle \\
& & & $\%$ & & \\
Control & & & & & \\
$1: 50$ & $98.8 \pm 0.3$ & $<1$ & & $97.9 \pm 0.6$ & $<1$ \\
$1: 250$ & $98.7 \pm 0.3$ & $<1$ & & $98.5 \pm 0.6$ & $<1$ \\
B-7 & & & & & \\
$1: 50$ & $99.2 \pm 0.3$ & $<1$ & & $98.1 \pm 0.4$ & $<1$ \\
$1: 250$ & $99.1 \pm 0.3$ & $<1$ & $98.2 \pm 0.5$ & $<1$ \\
& & & & & \\
\hline
\end{tabular}

* Mean of two to three hearts, $\geq 300$ grains counted per heart.

‡ After sera perfusion, hearts were fixed and prepared for immunocytochemical analysis using gold-labeled anti-IgG and gold particles quantified by electron microscopy. Similar results were obtained using protein A gold as a secondary label. Data are mean of three hearts with $\geq 300$ gold particles counted per heart. 
One alternative explanation for these findings is related to possible effects of insulin on capillary endothelial permeability (22). The unlabeled insulin could have had a generalized effect on endothelial cell permeability to all proteins independent of the proteins' ability to bind to capillary endothelial receptors. To test this possibility, studies were repeated using ${ }^{125} \mathrm{I}-\mathrm{DOP}$ insulin. The ${ }^{125} \mathrm{I}$-DOP insulin was similar to ${ }^{125} \mathrm{I}$-insulin in size, structure, and charge, but had little affinity for insulin receptors, therefore making it an appropriate probe to assess insulin receptor specificity. In studies with ${ }^{125} \mathrm{I}$-DOP insulin, unlabeled insulin, at concentrations of up to $10^{-5} \mathrm{M}$, had no effect on ${ }^{125} \mathrm{I}$-DOP insulin binding to capillaries or its appearance over cardiac muscle. Therefore, it is unlikely that the unlabeled insulin caused a decrease in muscle ${ }^{125} \mathrm{I}$-insulin by nonspecifically affecting the permeability properties of the capillary endothelium.

A second possible explanation for the findings of the present study would postulate a rapid, nonreceptor-mediated capillary uptake of insulin. In this respect, the data in Fig. 3 would simply reflect competition of labeled and unlabeled insulin for two distinct populations of insulin receptors, i.e., one group of receptors in capillary endothelium and the second in cardiac muscle. The data from experiments with trypsin and anti-insulin receptor antibodies argue against this explanation. When capillary insulin binding sites were destroyed by trypsin concentrations that did not grossly affect microvessel integrity $(0.2 \%$ trypsin), or when capillary receptors were blocked by anti-receptor antibodies, there was a decreased appearance of insulin in cardiac muscle. In both the trypsin and antireceptor studies, the degree of impaired insulin delivery to muscle was roughly proportional to the loss of capillary binding sites for insulin, suggesting a major role of the capillary receptors in the transfer of insulin from the vascular compartment to cardiac muscle. For the anti-receptor antibody studies, these findings occurred when an insignificant amount, if any, antibody had left the vascular compartment, ruling out a competitive effect of the antibodies at the level of cardiac muscle receptors for insulin. Thus, taken together, the data of the present study suggest that the capillary endothelial receptors for insulin have a central role in the transport of the majority of intact insulin that moved from the intravascular compartment to cardiac muscle. Furthermore, the proportionality between insulin binding to capillary receptors and the appearance of insulin in cardiac muscle suggests that the binding of insulin to the endothelial cell surface and not subsequent intraendothelial processing is normally the rate-limiting step in the transport of insulin to cardiac muscle.

Our findings have many potential physiologic and pathologic implications. At a minimum, they indicate an additional control point for the tissue action of insulin, namely the capillary endothelium. Alteration in endothelial function is already considered a characteristic finding in such disease processes as diabetes mellitus, a pathologic condition characterized by abnormalities of both the secretion of insulin and insulin action. In diabetes, retinal capillary beds demonstrate interendothelial leakage of small proteins, increased transcapillary exchange of plasma fluid components, and endothelial cell proliferation, with each of these findings preceding clinically detectable lesions of the retinal microvasculature $(23,24)$. Our data in the present study now suggest that certain capillary endothelia also serve to control the transcapillary movement of insulin, the hormone central to normal glucose homeostasis. With the at- tendant abnormalities of capillary endothelial function already described in diabetes, coupled with the thickened endothelial basement membrane that accompanies the disease, it is plausible that tissue levels of insulin are altered not only by diminished circulating levels of insulin but also by defective endothelial transfer of the hormone to the tissue.

The precise pathway required for the transendothelial movement of insulin, as well as other small molecular weight polypeptides, is uncertain. The data of the present study have been obtained in the rat heart, which contains capillary endothelia that are dominated by occluding intercellular junctions and a high degree of micropinocytotic vesiculation (17). In studies of analogous muscular capillaries with vesiculated endothelia having occluding interendothelial junctions, proteins as small as 1,550 D appear to pass through the capillary endothelial cell without permeating interendothelial cell junctions (25). Until recently, most authors agreed that the highly developed plasmalemmal vesicle system of these endothelia served as the transendothelial carriers of the small proteins, with vesicles pinching off at the lumenal or ablumenal surface, migrating across the cell, and finally discharging their contents at the opposite pole of the cell, a process designated transcytosis (25). More recent ultrastructural study of capillary endothelial cells have questioned the interpretation of the vesicular system as a discrete shuttle system. Both Bungaard (26) and Frokjaer-Jensen (27) have prepared three-dimensional reconstructions of endothelial segments from frog mesenteric capillaries and rat heart capillaries based on ultrathin serial sectioning. These authors have shown that the intraendothelial free vesicles observed on random thin sections are not true vesicles but parts of an elaborate caveolar system of interconnected invaginations of the lumenal and ablumenal surfaces. They suggest that such a static ultrastructural system is not compatible with active formation of discrete vesicles acting as transendothelial carriers. Thus, while the plasmalemmal vesicular system is thought to be critical for transendothelial passage of small proteins in capillaries such as those perfusing the myocardium, the details of such vesicular passage have not been elucidated.

In this regard, it is relevant to consider that not all capillary endothelium have occluding intercellular junctions, and that several capillary networks, particularly those of the central nervous system, may have occluding-type intercellular junctions but normally exhibit few intracellular endothelial vesicles (28). However, these capillary endothelial cells of the central nervous system can be induced to develop intracellular vesiculated structures in pathological conditions such as hypertension (29). Whether such diversity of endothelial morphology, coupled with differential surface affinities for the insulin molecule, would be factors controlling capillary transport of the hormone remain to be determined for each microvessel bed.

\section{Acknowledgments}

This work was supported by research funds from the Veterans Administration and by National Institutes of Health grants AM-25421 and DK-25295.

\section{References}

1. Bar, R. S., J. C. Hoak, and M. L. Peacock. 1978. Insulin receptors in endothelial cells: identification and characterization. J. Clin. Endocrinol. Metab. 47:699-702. 
2. Peacock, M. L., R. S. Bar, and J. C. Goldsmith. 1982. Interactions of insulin with bovine endothelium. Metab. Clin. Exp. 31:52-56.

3. King, G. L., S. M. Buzney, C. R. Kahn, N. Hetu, S. Buchwald, S. G. McDonald, and L. I. Rand. 1983. Differential responsiveness to insulin of endothelial and support cells from micro and macrovessels. J. Clin. Invest. 71:974-979.

4. vanHouten, M., and B. I. Posner. 1979. Insulin binds to brain blood vessels in vivo. Nature (Lond.). 282:623-625.

5. Frank, H. J. L., and W. M. Partridge. 1981. A direct in vitro demonstration of insulin binding to isolated brain microvessels. Diabetes. 30:757-761.

6. Pillion, D. J., J. F. Haskell, and E. Meezan. 1982. Cerebral cortical microvessels: an insulin sensitive tissue. Biochem. Biophys. Res. Commun. 104:686-692.

7. Bar, R. S., A. DeRose, W. Owen, A. Sandra, and M. Peacock. 1983. Insulin binding to microvascular endothelium of the intact heart: a kinetic and morphometric analysis. Am. J. Physiol. 244:E447-E452.

8. Berliner, J. A., D. P. Baker, A. M. VanLenten, A. M. Fogelman, and P. A. Cancilla. 1984. A comparison of lipoprotein endothelial interactions in aortic and capillary endothelial cells. Int. Symp. Biol. Vascular Endothel. Cell, 3rd, Cambridge, MA. 50.

9. Bar, R. S., S. Dolash, M. Boes, and B. L. Dake. 1986. Cultured capillary endothelial cells from bovine adipose tissue: a model for insulin binding and action in microvascular endothelium. Metab. Clin. Exp. 35:317-322.

10. Dernovsek, K. D., R. S. Bar, B. H. Ginsberg, and M. N. Lioubin. 1984. Rapid transport of biologically intact insulin through cultured endothelial cells. J. Clin. Endocrinol. Metab. 58:761-763.

11. Jialal, I., G. L. King, S. Buchwald, C. R. Kahn, and M. Crettaz. 1984. Processing of insulin by bovine endothelial cells in culture: internalization without degradation. Diabetes. 33:794-800.

12. Dernovsek, K. D., and R. S. Bar. 1985. Processing of cell-bound insulin by capillary and macrovascular endothelial cells. Am. J. Physiol. 248:E244-E251.

13. King, G. L., and S. Johnson. 1984. Receptor-mediated transport of insulin across endothelial cells. Science (Wash. DC). 227:1583-1586.

14. Bleehan, N. M., and R. B. Fisher. 1954. The action of insulin in the isolated rat heart. J. Physiol. 123:260-271.

15. Morgan, H. E., M. J. Henderson, D. M. Regen, and C. R. Park. 1961. Regulation of glucose uptake in muscle. J. Biol. Chem. 236:253-261.

16. Sudgen, P. H., and D. M. Smith. 1982. The effects of insulin on glucose uptake and lactate release in perfused working rat heart preparations. Biochem. J. 206:473-479.

17. Bruns, R. R., and G. E. Palade, 1968. Studies on blood capillaries. J. Cell Biol. 37:244-276.

18. Lioubin, M. N., M. D. Meier, and B. H. Ginsberg. 1984. A rapid high-yield method of producing mono[ $\left.{ }^{125} \mathrm{I}\right]-\mathrm{A}_{14}$ iodoinsulin. Prep. Biochem. 74:303-312.

19. Kahn, C. R., and L. C. Harrison. 1981. Insulin receptor autoantibodies: clinical and experimental studies. In Carbohydrate Metabolism and its Disorders. Vol. 3. P. J. Randle, D. F. Steiner, and W. J. Whelen, editors. Academic Press, Inc., Ltd., London. pp. 279-330.

20. Roth, J., M. Ravazzola, M. Bendayan, and L. Orci. 1981. Application of the protein A-gold technique for electron microscopic demonstration of polypeptide hormones. Endocrinology. 108:247253.

21. Jarrett, D. B., J. Roth, C. R. Kahn, and J. S. Flier. 1976. Direct method for detection and characterization of cell surface receptors for insulin by means of ${ }^{125} \mathrm{I}$-labeled autoantibodies against the insulin receptor. Proc. Natl. Acad. Sci. USA. 73:4115-4119.

22. Osterby, R., H. J. D. Gundersen, and N. J. Christensen. 1978. The acute effect of insulin on capillary endothelial cells. Diabetes. 27:745-749.

23. Cunha-Vaz, J. G., F. J. R. deAbreu, A. J. Campos, and G. M. Figo. 1975. Early breakdown of the blood-retinal barrier in diabetes. Br. J. Ophthalmol. 59:649-656.

24. Sosula, L., P. Beaumont, F. C. Hollows, and K. M. Jonson. 1972. Dilatation and endothelial proliferation of retinal capillaries in streptozotocin-diabetic rats: quantitative electron microscopy. Invest. Ophthalmol. 11:926-935.

25. Simionescu, M., N. Simionescu, and G. E. Palade. 1975. Segmental differentiations of cell junctions in the vascular endothelium: The microvasculature. J. Cell Biol. 67:863-885.

26. Bundgaard, M. 1983. Vesicular transport in capillary endothelium: does it occur. Fed. Proc. 42:2425-2430.

27. Frokjaer-Jensen, J. 1984. The plasmalemmal vesicular system in striated muscle capillaries and in pericytes. Tissue Cell. 16:31-42.

28. Reese, T. S., and M. J. Karnovsky. 1967. Fine structural localization of the blood-brain barrier to exogenous peroxidases. J. Cell Biol. 34:207-217.

29. Westergaard, E., B. vanDeurs, and H. E. Brondsted. 1977. Increased vesicular transfer of exogenous peroxidases across cerebral endothelium evoked by acute hypertension. Acta Neuropathol. 37:141-152. 